\title{
CONTENTS - INHALT
}

1. Preface - Vorwort

2. Directions for use - Anweisung zum Gebrauch

3. Concordance - Konkordanz

4. Appendix 